\title{
Errata
}

Volume 46 (1) of the Review of Middle East Studies contained a very fine special section put together by Professor Fariba Zarinebaf, titled "Mediterranean Encounters." Unfortunately, due to an editorial error on my part, the introduction to the special section was omitted, and thus readers were left without important context for understanding the origin and relationship between the articles. The full introduction to the special section appears below. My apologies to Professors Zarinebaf, Burke, Darling, Fromherz, and Lisy-Wagner.

Gregory Starrett

Past Editor

\section{Encounters in the Mediterranean}

Edited by Fariba Zarinebaf

The following articles were selected from a group of excellent papers presented in the University of California World History and Mediterranean Research Group (MRG) conference organized by Fariba Zarinebaf and Edmund Burke entitled, "Encounters in the Mediterranean," at the University of CaliforniaRiverside in May 2010.

The papers, ranging from ancient to the present times, invoked a world history theme within a comparative framework that bears upon the Mediterranean. The topics included 1) ancient world history and the Mediterranean (including the Indo-Mediterranean); 2) methodological discussions of the Mediterranean in world history in the light of work on other world spaces; 3 ) the Mediterranean and/in the world after 1492;4) the Mediterranean and its neighbors: Africa, W. Europe, E. Europe, Central Asia, South Asia; 5) the roots of the modern Mediterranean; 6 ) and attempts to study other maritime spaces (Indian Ocean, South China Sea, the Atlantic) using the templates derived from studies of the Mediterranean.

We selected the papers by Edmund Burke, Linda Darling, Allen Fromherz, Laura Lisy-Wagner, and Fariba Zarinebaf that focused more specifically on the Middle East and North Africa. They offer theoretical frameworks (Darling and Burke), debates within the field (Fromherz), a fresh look at travel accounts in mapping the Mediterranean world (Lisy-Wagner), and a case study on 
inter-confessional life in Istanbul, one of Mediterranean's largest and most diverse metropolises (Zarinebaf).

Edmund Burke III proposes a comparative history of the Mediterranean to conceptualize an alternative model of modernity. He is critical of the narratives put forward by western scholars on "what went wrong" and the failure of Muslims to measure up to European modernity. He underlines similarities and common obstacles to the process of modernization in the Mediterranean North and South, such as demographic decline, agricultural downturn and the shift in global exchange. He argues that the liberal reform projects introduced by colonial powers like France and England created tensions and social cleavages among the elites, peasants, workers and religious groups in their respective colonies. Social unrest and contestation over the question of religion in public life and gender roles marked the political discourse and cultural wars of the long nineteenth century in the Mediterranean world.

Darling proposes to study the Mediterranean as a borderland between the Christian and Muslim civilizations and borrows theoretical frameworks from the study of the American Southwest developed by Oscar Martinez and William Zartman. She differentiates between the concepts of the frontier which lay on the edge of civilizations, and that of the borderland which was an open and unique human environment distant from the center and exposed to transnational trends, migration, unique institutions, values, and customs that created peaceful coexistence as well as tensions.

Fromherz takes this idea further, to study contacts and cross-border activities between the Muslim North Africa and the Christian Mediterranean. He challenges the existing historiography that separates North Africa from the Western Mediterranean. He is also critical of the works of French Annalists who describe the history of the Maghrib as part of the history of colonial France and Western Mediterranean. Postcolonial anti-structuralist narratives, on the other hand, ascribe regional distinctiveness and agency to Maghribi history that isolate the history of North Africa from the rest of the Mediterranean. Hybridity and connectivity, similar to the concept of borderland, may be a more appropriate term, according to Fromherz, to understand the history of the medieval Mediterranean.

Lisy-Wagner's essay on a fifteenth century Czech traveler to Jerusalem, maps the multicultural space between the borderlands of Central Europe, Venice, and the Ottoman Empire as one interconnected unit, an integrated borderland, or a "region of diversity within unity" to quote David Abulafia (The Mediterranean in History, 2003). 
Zarinebaf applies the model of patchy and layered borderland put forward by William Zartman to the port city of Istanbul. She argues that Istanbul could be studied as a borderland between Christiandom and Islamdom, where confessional communities enjoyed a fair degree of communal and legal autonomy from the state until the nineteenth century. She also shows that porous legal boundaries allowed for interaction across the confessional and communal boundaries while the law courts accommodated religious difference as well as co-existence. The Islamic courts and the kadi functioned as the final arbiter when non-Muslims sought legal recourse to the shari'a. Zarinebaf argues that the degree of tolerance shown by confessional states toward their religious and ethnic minorities depended on political and economic conditions as well as a pluralist legal system. Although Ottoman Istanbul was far more diverse in its ethno-religious makeup than other Mediterranean port cities due to Ottoman policies of settlement, migration, and legal pluralism, at times of heightened conflict, the state punished those who crossed the religious and sexual boundaries of their communities. Accommodation as well as conflict characterized the lives of confessional communities in the early modern Mediterranean. $\%$ 